\title{
THE EFFECTS OF DISTRIBUTED LEADERSHIP ON TEACHERS' COLLECTIVE EFFICACY AND PROFESSIONAL LEARNING COMMUNITY
}

\author{
Mohd Fadzil Jamil \\ Academic Management Sector, Educational Department of Negeri Sembilan \\ (drwnacs@gmail.com) \\ Mohd Izham Mohd Hamzah \\ Center of Educational Leadership \& Policy \\ Faculty of Education, Universiti Kebangsaan Malaysia \\ (izham@ukm.edu.my)
}

\begin{abstract}
Distributed leadership offers a new-thinking in transforming the school's leadership. Teachers' collective efficacy and professional learning community have been identified to have a strong influence on improving the teaching quality of teachers. This article examines the effects of distributed leadership of secondary school administrators on teacher collective efficacy and professional learning community. The literature suggests that distributed leadership perspective is a good alternative strategy to improve the quality of educational institutions, but empirical evidence showing the effects of distributed leadership on teachers' collective efficacy and professional learning community that can improve the quality of teacher's teaching is limited. Data were collected from 592 teachers working in secondary schools in Negeri Sembilan, Malaysia. Distributed leadership of secondary school administrators were determined with Distributed Leadership Inventory developed by Hulpia (2009) while teachers' collective efficacy was determined using the Collective Efficacy Scales developed by Goddard and Hoy (2003) and professional learning community was determined with the School Professional Staff as Learning Community Questionnaire developed by Hord (1996). Data analysis was done based on Structural Equation Modeling using AMOS software. Regression weight, variance and squared multiple correlations tests were used in data analysis. In conclusion, a strong positive relationship was revealed between distributed leadership of secondary school administrators on teachers' collective efficacy and professional learning community. Distributed leadership of secondary school administrators was also a significant predictor of teachers' collective efficacy and professional learning community.
\end{abstract}

Keywords: Distributed Leadership, Teachers' collective efficacy, Professional Learning Community, Effect. 


\section{INTRODUCTION}

Challenges of the current globalization era and the challenges of making schools as a future learning organization as embedded in the Malaysia Education Development Plan 20132025 have urged school leaders and administrators to look for ways to make their organizations more flexible. Therefore, for the reformation of the system as a whole, the leadership aspect should be viewed as a collective rather than an individual leader's capacity (Fullan 2010).

One type of school leadership that researchers focus on today is distributed leadership. The concept of distributed leadership is not solely about the leadership of a school leader, but it is a process of leadership shaped by the daily interactions between school leaders (school administrators) and school organization members (Spillane et al. 2004). In this context, leadership tasks are accomplished through the interaction of several individual leaders (Spillane et al. 2001, 2004).

Leadership factors are important in determining school success because the burden of responsibility and accountability of school success and student academic achievement rests on the shoulders of school leaders (Jazzar \& Algozzine 2007; Leithwood \& Louise 2012). However, literatures and previous studies have found that school's principals are not directly involved in classroom activities, especially in areas where school principals are required to implement the functions of curriculum leaders such as curriculum development programs, assessment and supervision of teachers, teacher's professional development and improvement programs (Hallinger \& Murphy 2013; James Ang \& Balasandran 2009; Wahlstrom et al. 2010; Wahlstrom \& Louis 2008), as a result of the routine of day-to-day management and administration (Abdullah et al. 2012; Horng et al. 2010; Kowalski 2010).

Literature shows that the impact of principal leadership on students' academic achievement is through the actions of principal leadership that can influence the organization, teachers, and classroom teaching practices (Leithwood et al. 2008; Leithwood \& Louise 2012; Marzano et al. 2005). In addition, the literature has identified two factors of teacher capacity namely teachers' collective efficacy (Goddard et al. 2004) and professional learning community (Hord 2008, 2009) that have a powerful influence on the quality of teaching of teachers.

Although some researchers have suggested that the distributed leadership perspective is a good alternative strategy for improving the quality of educational institutions (Harris 2003; Harris \& Spillane 2008; Mascall et al. 2009), the empirical evidence showing the relationship and the association of distributed leadership with teachers' collective efficacy and professional learning community that can improve teacher quality of teaching is

International Journal of Educational Best Practices (IJEBP)

Vol. 3 No. 2 October 2019

ISSN: 2581-0847

DOI: 10.31258/ijebp.v3n2.p10-27 
limited. Therefore, research that would provide evidence that distributed leadership has a significant effect on the teachers' collective efficacy and professional learning community will further reinforce the relevance of distributed leadership among school principals.

\section{LITERATURE REVIEW}

\section{Distributed Leadership}

There are various definitions for the term distributed leadership given by researchers in the leadership field. Among them, distributed leadership is defined as a dynamic interaction between several leaders and their followers in performing their duties and responsibilities (Timperley 2005). The main focus of distributed leadership is to mobilize leadership at all levels of the organization and not rely solely on a single top leadership (Harris 2008) and distributed leadership is understood as a collective social process resulting from interactions involving multiple leaders (Uhl-Bien 2006).

\section{Distributed Leadership Framework by Gronn (2002)}

According to Gronn (2002), distributed leadership is referred to as a dimension of collective action. The joint action is characterized by three forms of engagement in leadership, namely, (i) spontaneous cooperation, ii) intuitive working relationships and iii) institutionalized practice (Gronn 2002). In the perspective of the distributed leadership, these three forms of engagement work collectively in an organization.

\section{Distributed Leadership Framework by Spillane et al. (2004) and Spillane (2007)}

The distributed leadership framework by Spillane et al. (2004) described distributed leadership as a distribution of leadership activities and functions through the involvement of several leaders and followers in performing leadership tasks. The distributed leadership framework takes into account the context of the socio-cultural as the cornerstone of leadership practice, making the situation as an important element in determining the activity of leadership (Spillane et al. 2004).

In the process of developing the knowledge of school leadership and administration, Spillane and Diamond (2007) have developed a conceptual framework of distributed leadership perspectives that involves two aspects: leader-plus aspect and practice aspect. 
The leaders-plus aspect recognizes the contributions of other individuals (those who are officially in the administration and from those who are not in the administration) who also help and take responsibility in leading and managing (Spillane \& Diamond 2007).

The practice aspect is referred to as a framework resulting from the interactions between school leaders, followers (teachers) and situations (Spillane \& Diamond 2007).

\section{Distributed Leadership Model by Hulpia and Davos (2009)}

The Distributed Leadership Model by Hulpia and Davos (2009) has adopted the distributed leadership theory framework by Spillane and Diamond (2007) and distributed leadership theory by Gronn (2002) as the basis for the model. The Distributed Leadership Model developed by Hulpia and Davos (2009) states that distributed leadership comprises of three main dimensions:

\section{The Distribution of leadership functions among groups of official leaders.}

This dimension of distributed leadership is limited to individuals who serve as formal school leaders, principals, assistant principals, and teacher leaders (Hulpia et al. 2009). It focuses on two leadership functions which are: i) supporting leadership functions and, ii) supervisory leadership functions.

These two leadership functions are based on the leadership functions that can be found in the Teaching Leadership Model by Phillip Hallinger (2003) and in the Transformational Leadership Model by Leithwood and Jantzi (1999). The supporting leadership functions include two key elements of the transformational leadership model, which are: i) building and setting school vision collectively, and ii) motivating members in the organization. As for the supervisory leadership functions, it focuses on the role of leaders in supervising teachers, especially in the classroom (Hallinger 2003, 2005, 2011).

\section{Team Leadership.}

The team leadership dimension links the aspects of concerted action within the distributed leadership framework by Gronn (2002) and the interrelationship aspects of the distributed leadership framework by Spillane and Diamond (2007). This dimension is very important because teamwork is a crucial element in defining distributed leadership (Hulpia et al. 2009a) and it is developed by three elements: team cohesion, goal-oriented, and role clarity.

Team cohesion in this dimension refers to a process by which a sense of "belonging" or "togetherness" within members in the group. Goal-oriented, however, refers to the vision and mission of the organization shared by all team 
members. Whereas role clarity refers to the clear division of roles in management and leadership.

\section{Participation/involvement of teachers in decision making.}

In this model, the dimension of teacher participation/involvement in decision making looks to the extent to which teachers are involved in the decision-making process at school. The involvement of teachers in decision making is an important element in the distributed leadership model (Muijs \& Harris 2006).

\section{Teachers' Collective Efficacy}

Teachers' collective efficacy refers to the perception of teachers' belief that the collective effort of all members of the organization as a whole will positively have an impact on student's achievement (Goddard et al. 2004). Teachers' collective efficacy is defined of two-element namely; 1) analysis of teaching tasks and, 2) assessment of teaching competency.

\section{Analysis on Teaching Tasks.}

Analysis of teaching tasks refers to teachers analyzing factors that may contribute to the success of their teaching activities in the school including barriers or constraints; teachers ability to provide appropriate understanding to all students, teachers' confidence to motivate students, supportive communities to support student learning, student's living environments, concerns about student safety in schools and, social problems in the communities that may make learning difficult for student (Goddard et al. 2004).

\section{Assessment on Teaching Competency}

The assessment of teaching competency will create a positive belief in the faculty/committee as well as confidence in the teachers that all students in their school can learn and be successful; teachers tendency to give up on students who do not want to learn, the skills required by teachers to produce meaningful learning for students, teacher's confidence in students' ability to learn, student readiness, student self-motivation and, teacher's ability to deal with disciplinary problems student (Goddard et al. 2004).

\section{Professional Learning Community}

The professional learning community is defined in five dimensions; a) shared and supportive leadership, b) shared values, goals, mission and vision, c) collective learning and application, d) personal practice sharing and, e) supportive conditions (Hord 2004). 


\section{Shared and Supportive Leadership}

According to Hord (2004), the shared and supportive leadership refers to the democratic practice of school administrators and teachers in terms of powersharing, authority, and decision-making.

\section{Shared Values, Goals, Mission and Vision}

According to Hord (2004), the shared values, goals, missions and visions mean that the visions and the positive values of the school are shared among the school administrators and the teachers to improve school performance.

\section{Collective Learning and Application}

According to Hord (2004), collective learning and the application refers to the practices of collective learning among the teachers and using the learning outcomes to address student learning needs.

\section{Sharing of Personal Practice}

According to Hord (2004), sharing of personnel practice refers to the practice of giving peer reviews and peer feedback on the quality of teaching that has been implemented by an individual teacher in an effort to enhance individual and organizational capacity.

\section{Supportive Conditions}

According to Hord (2004), the dimensions of supportive conditions are the conditions and the capacities available in the schools that can support teachers to form a professional learning organization. It involves two aspects, a) the relationship aspect and, b) the structural aspect.

\section{a) Relationship Aspect}

Relationship aspect includes; caring relationships that exist between teachers and students based on trust and respect, the creation of a culture of trust and respect, regularly recognize and celebrate academic achievement and, the continuing efforts of teachers and stakeholders (communities and student's families) to incorporate change into the school culture (Hord 2004).

b) Structural Aspect

Structural aspect includes; working collaboratively to allocate tasks to teachers, forming a school schedule that promotes teacher collective learning and sharing practices, allocating financial resources for professional development programs or activities, providing technology facilities to assist teaching, supplying appropriate teaching materials for teachers, the ability of the school to acquire specific individual expertise to support the continuous 
learning of the teachers, maintaining conducive school's environment, the positioning of teachers to facilitate collaboration among teachers, providing efficient communication system that facilitates the flow of information to teachers and the school community, including office staffs, parents, and members of the local community (Hord 2004).

\section{RESEARCH PURPOSE}

The main purpose of this study was to determine the effects of school administrators' distributed leadership on teachers' collective efficacy and professional learning community.

\section{RESEARCH OBJECTIVES}

The specific objectives of the study are as follows:

1. To identify the level or state of distributed leadership, teachers' collective efficacy and professional learning community.

2. To determine whether distributed leadership of school administrators has a significant effect on teachers' collective efficacy.

3. To determine whether the distributed leadership variable has a significant effect on professional learning community.

\section{RESEARCH QUESTIONS}

The researcher wishes to find the answers to the following research questions:

1. What are the level/state of distributed leadership, teachers' collective efficacy and professional learning community?

2. Does distributed leadership of school administrators have any effect on teachers' collective efficacy?

3. Does distributed leadership of school administrators have any effect on professional learning community?

\section{RESEARCH HYPOTHESES}

Based on the objectives and research questions, two hypotheses have been detailed:

1. Ho1: The regression relation of distributed leadership on teachers' collective efficacy is significant.

2. Ho2: The regression relation of distributed leadership on professional learning community is significant. 


\section{METHOD}

\section{Research Design}

This quantitative research method is based on the causal relationship design using a questionnaire as the main instrument for the study. The research sample consisted of secondary school teachers in Negeri Sembilan, Malaysia

\section{Sample}

The study was carried out in secondary schools in Malaysia. The participants for this study consisted of 960 secondary school teachers located at 60 secondary schools in the province of Negeri Sembilan, Malaysia. A total of 592 teachers representing the response rate of $61.7 \%$, responded to the questionnaires. Of the teachers, $29.6 \%$ were males and $70.4 \%$ were females. With regards to teaching experience, $23.6 \%$ had been working for $1-5$ years, $17.1 \%$ for $6-10$ years and $58.3 \%$ for more than 10 years. Of the teachers, $4.7 \%$ had a diploma, $83.6 \%$ had a bachelor degree, $11.7 \%$ had a master degree and $0.2 \%$ had a doctorate.

\section{Research Instrument}

To address the research questions and hypotheses, data were collected using the main instrument of the study in which the items were adapted and modified from three existing instruments; Distributed Leadership Inventory (DLI) developed by Hulpia (2009), the Collective Efficacy Scales (CE-SCALE) instrument developed by Goddard and Hoy (2003) and the School Professional Staff as Learning Community Questionnaire (SPSLC) instrument by Shirley Hord (1996).

\section{Data Analysis}

Structural Equation Modeling (SEM) method with the help of AMOS software was used for the data analysis. Regression weight analysis was carried out to explore whether a relationship exists between distributed leadership and teachers' collective efficacy and also between distributed leadership and professional learning community. Variance analysis was used to determine whether distributed leadership significantly able to predict changes in teachers' collective efficacy and professional learning community. Whereas, squared multiple correlations test was carried out to determine how much the variance in the teachers' collective efficacy and the variance in a professional learning community can be predicted by distributed leadership in the regression model. Thus, the effect of distributed leadership of secondary school administrators on teachers' collective efficacy and 
professional learning community were tested by utilizing variance and squared multiple regression analysis.

\section{RESULT}

Mean and standard deviation values of the level of school administrators distributed leadership; teachers' collective efficacy and professional learning community are presented in Table 1. From Table 1, it can be seen that the mean scores of distributed leadership (4.19), teachers' collective efficacy (4.01) and professional learning community (4.10). As a whole, all three variables were above the midpoint 4.0 on the rating scale. Table 1 shows that the level of distributed leadership (mean: 4.19) was higher than the professional learning community (mean: 4.10) and teachers' collective efficacy (mean: 4.01).

Table 1. Descriptive statistics of distributed leadership, teachers' collective efficacy, and professional learning community.

\begin{tabular}{lccc}
\hline Variable & Mean & $\begin{array}{l}\text { Standard } \\
\text { deviation }\end{array}$ & Level \\
\hline Distributed leadership & 4.19 & .640 & High \\
Teachers' collective efficacy & 4.01 & .726 & High \\
Professional learning community & 4.10 & .563 & High \\
\hline
\end{tabular}

Research Hypothesis Testing

\section{Ho1 Testing}

\begin{tabular}{ll}
\hline $\begin{array}{l}\text { Hypothe } \\
\text { sis }\end{array}$ & \multicolumn{1}{c}{ Research hypothesis } \\
\hline Ho1 & $\begin{array}{l}\text { The regression relation of distributed leadership on teachers' collective } \\
\text { efficacy is significant. }\end{array}$ \\
\hline
\end{tabular}

\section{a) Regression Weight Analysis}

Table 2 below shows the result of the regression weight analysis between distributed leadership (KT) and teachers' collective efficacy (EKG). 
Table 2. Analysis of regression weight under the unstandardized estimates readings of the structural model for hypothesis testing, Ho1

\begin{tabular}{|c|c|c|c|c|c|}
\hline & $\begin{array}{c}\text { Estimates : } \\
\text { (The Actual Beta } \\
\text { Values) }\end{array}$ & $\begin{array}{l}\text { Standard } \\
\text { Error S.E. }\end{array}$ & $\begin{array}{c}\text { Critical Ratio } \\
\text { C.R. } \\
\text { (z) }\end{array}$ & $\mathbf{P}$ & (Result) \\
\hline KT -> EKG & 1.119 & .106 & 10.569 & $* * *$ & Significant \\
\hline
\end{tabular}

The results of the maximum likelihood estimates analysis showed that the critical ratio, C.R value of the standard regression coefficient for the distributed leadership (KT) variable against the teachers' collective efficacy $(\mathrm{EKG})$ variable is significant (outside the range of \pm 1.96 ). For the KT $\rightarrow$ EKG route, the value of C.R. $=10.569$ and regression coefficient values, $\beta=1.119$ indicates that there is a significant relationship between the two variables. (C.R. $=10.569, \beta=1.119, \mathrm{p}<0.001$ ).

The results of the regression weight analysis, KT-> EKG showed that the regression coefficient value, $\beta=1.119$. This explains that when distributed leadership variable (KT) goes up by 1 unit, the teachers' collective efficacy variable (EGK) will go up by 1,119 units. The value of C.R. $=10.569$ indicates that the probability of getting a critical ratio, C.R of 10.569 in absolute value is less than 0.001 . In other words, the regression weighting for distributed leadership (KT), in the prediction of teachers' collective efficacy (EKG) is significantly different from zero at level 0.001 (twotailed). Thus, the research hypothesis is supported.

\section{b) Variances and Squared Multiple Correlations Analysis}

Table 3 shows the variance analysis while Table 4 shows the squared multiple correlations analysis of the distributed leadership (KT) -> teachers' collective efficacy (EKG).

Table 3. Variances analysis

\begin{tabular}{ccccc}
\hline & Estimates & S.E. & C.R. & P \\
\hline KT & 0.081 & 0.013 & 6.174 & $* * *$ \\
\hline$* * *$ indicate a highly significant at $<0.001$ & & &
\end{tabular}

Table 4. Squared multiple correlations analysis

\begin{tabular}{cc}
\hline & Estimates \\
\hline EKG & $\underline{0.699}$ \\
\hline
\end{tabular}

The results of Table 3 shows the estimated value of variance, (variance estimates) KT $=0.081$ is significant $($ S.E. $=0.013$, C.R. $=6.174, p<0.001)$. It is found that the value of C.R. is above the value of 1.96. This indicates that the distributed leadership (KT) exogenous variable in the regression model is significantly capable of predicting 
changes in the teachers' collective efficacy (EKG) endogenous variable.

Results from Table 4 shows the variance value of the teachers' collective efficacy $(\mathrm{EKG})$ endogenous variable predicted by the distributed leadership (KT) exogenous variable for the KT $\rightarrow$ EKG pathway. Estimates $=0.699$ (C.R. = 6.174, p <0.001) indicated that $69.9 \%$ of the variance in the teachers' collective efficacy (EKG) variable could be predicted by the distributed leadership (KT) variable and that $30.1 \%$ of the variance in the teacher collective efficacy $(\mathrm{EKG})$ variable could not be predicted by this regression model. This means that $30.1 \%$ of the other changes were due to other factors (zl), which were not predicted by the distributed leadership (KT) variables in this structural equation model.

\section{c) Conclusion on Ho1 Testing}

The results of the maximum likelihood estimates analysis show the value of C.R. the standardized regression coefficient between the distributed leadership (KT) variable and teachers' collective efficacy (EKG) variables was significant (C.R. $=10.569, \beta=$ $1.119, \mathrm{p}<0.001$ ). The results in the variance table (Table 3 ) and the squared multiple correlations table (Table 4) showed that significantly, the predictable variance value of the EKG -> EKG path was .699 or $69.9 \%(\mathrm{CR}=6.174$, p <0.001 ). In this case, $69.9 \%$ of the variance in the teachers' collective efficacy $(\mathrm{EKG})$ variable could be predicted by the variance in the distributed leadership (KT) variable. Based on these results, the hypothesis of Ho1 is supported.

\section{Ho2 Testing}

\begin{tabular}{ll}
\hline Hypothesis & \multicolumn{1}{c}{ Research hypothesis } \\
\hline Ho 2 & $\begin{array}{l}\text { The regression relation of distributed leadership on professional learning } \\
\text { community is significant }\end{array}$ \\
\hline
\end{tabular}

\section{a) Regression Weight Analysis}

Table 5 below shows the results of regression weights analysis between distributed leadership (KT) and the professional learning community (KPP).

Table 5. Analysis of regression weights under the unstandardized estimates reading of the structural model for hypothesis testing, $\mathrm{Ho} 2$

\begin{tabular}{lccccc}
\hline & $\begin{array}{c}\text { Estimates : } \\
\text { (The Actual Beta }\end{array}$ & $\begin{array}{c}\text { Standar } \\
\text { d Error }\end{array}$ & $\begin{array}{c}\text { Critical } \\
\text { Ratio }\end{array}$ & P & \\
Kalues) & S.E. & C.R. & & Result \\
KT $>$ KPP & 1.182 & .115 & 10.284 & $* * *$ & Significant \\
\hline$* * *$ indicate a highly significant at $<0.001$ & & &
\end{tabular}


The results of the maximum likelihood estimates analysis show that the critical ratio, C.R value of the standard regression coefficient between the distributed leadership (KT) variable and professional learning community (KPP) variable with their indicator variables are significant (outside the range of \pm 1.96 ). For the KT $\rightarrow$ KPP route, the value of C.R. $=10.284$ and regression coefficient values $(\beta=1.182)$ indicate that there is a significant relationship between the two variables. (C.R. $=10.284, \beta=1.182, p$ $<0.001)$.

Regression weight analysis for KT-> KPP, shows that regression coefficient value, $\beta=$ 1.182. This explains that when distributed leadership variable (KT) goes up by 1 unit, the professional learning community variable (KPP) will also go up by 1,182 units. The value of C.R. $=10.284$ shows that the probability of getting a Critical ratio, C.R of 10.284 in absolute value is less than 0.001 . It shows that the regression weighting for distributed leadership (KT) in the prediction of the professional learning community (KPP) is significantly different from zero at the 0.001 level (two-tailed). In other words, the research hypothesis is supported.

\section{b) Variances and Squared Multiple Correlations Analysis}

Table 6 shows the variance analysis and Table 7 shows the squared multiple correlations analysis of the distributed leadership (KT) $\rightarrow$ professional learning community (KPP).

Table 6. Variance analysis.

\begin{tabular}{ccccc}
\hline & Estimates & S.E. & C.R. & P \\
\hline KT & 0.081 & 0.013 & 6.174 & $* * *$ \\
\hline
\end{tabular}

*** indicate a highly significant at $<0.001$

Table 7. Squared multiple correlations analysis.

\begin{tabular}{cc}
\hline Estimates \\
\hline KPP & $\underline{0.835}$ \\
\hline
\end{tabular}

The results of Table 6 show the estimated value of variance, (variance estimates) KT = 0.081 is significant $($ S.E. $=0.013$, C.R. $=6.174, p<0.001)$. It is found that the value of C.R. is larger than \pm 1.96 . This indicates that the distributed leadership (KT) exogenous variable in the regression model can significantly predict the change in the professional learning community (KPP) endogenous variable.

The results of Table 7 show the value of variance in professional learning community (KPP) endogenous variable predicted by distributed leadership (KT) exogenous variable for KT $\rightarrow$ KPP pathway. Estimated value $=0.835($ C.R. $=6.174, p<0.001)$ indicates that as much as $83.5 \%$ of the variance in professional learning community (KPP) variables can be predicted by the distributed leadership (KT) variable. This 
means that $16.5 \%$ of the variance in the professional learning community (KPP) variables cannot be predicted by this regression model. This means that $16.5 \%$ of the other changes were due to other factors (zl), which were not predicted by the distributed leadership (KT) variables in this structural equation model.

\section{c) Conclusion on Ho2 testing}

The results of the maximum likelihood estimates analysis show the value of C.R. the standardized regression coefficient between distributed leadership (KT) and professional learning community (KPP) variables was significant (C.R. $=10.284, \beta=$ $1.182, \mathrm{p}<0.001$ ). The results in the variance table (Table 6) and the squared multiple correlations table (Table 7) show that significantly, the predictable variance value for the KT $->$ KPP path was .835 or $83.5 \%(C R=6.174, p<0.001)$. In this case, $83.5 \%$ of the variance in the professional learning community (KPP) variable can be predicted by the variance in the distributed leadership (KT) variable. Based on these results, the research hypothesis $\mathrm{Ho} 2$ is supported.

\section{DISCUSSION}

\section{The Effect of Distributed Leadership on Teachers' Collective Efficacy}

The findings showed that there is a significant relationship of influence and effect of distributed leadership variable on teachers' collective efficacy variable. The results of this study clearly indicate that if the distributed leadership (KT) variable increases by 1 unit, then the teachers' collective efficacy (EKG) variable will also increase by 1.119 units. The findings also showed that the distributed leadership (KT) exogenous variable in the regression model was significantly able to predict $69.9 \%$ variance in the teachers' collective efficacy (EKG) endogenous variable.

Therefore, the findings of this study significantly indicated that the distributed leadership variable has a strong and positive effect on the teachers' collective efficacy variable. This is because any increase in the value of the distributed leadership variable will also lead to an increase in the teachers' collective efficacy variable. The study also concluded that distributed leadership variables were able to predict $69.9 \%$ of the variance in the teachers' collective efficacy variables. This clearly indicates that the distributed leadership variable can significantly predict changes in the teachers' collective efficacy variable.

The findings in this research are in line with some other previous findings. Among them, the findings of this study supported the findings of Camburn and Han (2009), Hallinger and Heck (2009) and Leithwood et. al (2009) which also found that distributed leadership has a positive effect on teacher self-efficacy, teacher self-motivation and positive relationships

International Journal of Educational Best Practices (IJEBP)

Vol. 3 No. 2 October 2019

ISSN: 2581-0847

DOI: 10.31258/ijebp.v3n2.p10-27 
with certain student learning outcomes.

Overall, this study shows that distributed leadership variable has a strong and positive impact on the teachers' collective efficacy variable. Therefore, the findings of this study highlighted the importance of distributed leadership practiced by the school administrators in order to create a high level of teachers' collective efficacy in schools.

\section{The Effect of Distributed Leadership on Professional Learning Community}

The findings show that there are a significant impact and influence of distributed leadership variable on the professional learning community variable. The findings show that if the distributed leadership variable increases by 1 unit, then the professional learning community variable will also increase by 1.182 units. In addition, the study also shows that the distributed leadership (KT) exogenous variable in the regression model can significantly predict $83.5 \%$ change in variance within the professional learning community (KPP) endogenous variable.

The findings of this study are in line with the findings that show distributed leadership has a high impact on the formation of professional learning communities in schools (Pedersen et al. 2010). The study by Pederson et al. (2010) reported that the success of forming a professional learning community is not only aided by the practice of distributed leadership, but also depends on the extent to which school administrators who practice distributed leadership appears to be actively engaged with teachers to produce a good teaching session.

Overall, these findings significantly indicate that the distributed leadership variable has a strong influence on the professional learning community variable. This is because the findings indicate that any increase in the distributed leadership variables will also lead to an increase in the professional learning community variable. It is clear that the practice of distributed leadership among school administrators has the influence and effect of enhancing the practice of the professional learning community among teachers in the school. In addition, the findings also show that the distributed leadership variable can significantly predict changes in the variables of the professional learning community.

\section{CONCLUSION AND IMPLICATIONS}

An aspect of school leadership is meeting the needs of teachers to improve the quality of teaching. The understanding of distributed leadership may contribute to improving teacher's quality of teaching due to its characteristics such as supporting, sharing of power, active interaction and communication between school administrators and teachers. Taking into consideration the findings in this study that distributed leadership has a positive effect 
on teachers' collective efficacy and professional learning community, it can be said that school administrators should aim to adopt distributed leadership in order to improve teacher's quality of teaching.

The results of this study may also be evaluated in terms of developing school principals and educational policies. School administrators are the front line of school leadership. They are the ones who will shape the climate as well as the direction and the mission of the school. Therefore, school administrators should be guided on how to practice distributed leadership (Harris 2008).

The results of this study are limited to the opinions of teachers in secondary schools in Negeri Sembilan, Malaysia. Although this study reveals evidence that shows the positive effect between distributed leadership on teacher collective efficacy and professional learning community, the results reflect the characteristics and perceptions of the individuals working in schools where the research was conducted. For this reason, studies carried out in different places are needed for a generalization of the results obtained in this research. Hence, it is recommended that research on the effects of distributed leadership on teachers' collective efficacy and professional learning community should also be carried out in different places.

In conclusion, the findings of this study provide a significant reflection of the contribution of distributed leadership in relation to the effect on teacher capacity factors in schools namely the teachers' collective efficacy and professional learning community. The findings of the study show that distributed leadership is significantly related to both factors. Therefore, the researchers conclude that the distributed leadership aspect is a significant factor in driving the school towards excellence.

\section{REFERENCES}

Abdullah, M. Y., Zain, S., Mohamad, B., Ambotang, A. S., Taat, M. S. \& Talip, R. (2012). Kepimpinan Instruksional Pengetua: Cabaran Dan Harapan. Utusan Borneo B4.

Fullan, M. (2010). All Systems Go: The Change Imperative for Whole System Reform. Corwin Press.

Goddard, R. D., Hoy, W. K. \& Hoy, A. W. (2004). Collective Efficacy Beliefs: Theoretical Developments, Empirical Evidence, and Future Directions. Educational researcher, 33(3),3-13. 
Goddard, R. D., Hoy, W. K. \& Hoy, A. W. (2004). Collective Efficacy Beliefs: Theoretical Developments, Empirical Evidence, and Future Directions. Educational researcher 33(3): 3-13/

Gronn, P. (2002). Distributed Leadership. Dlm. Leithwood, K. \& Hallinger, P. (pnyt.). Second International Handbook of Educational Leadership and Administration, hlm. 653-696. Dordrecht: Kluwer Academic Publisher.

Hallinger, P. (2003). Leading Educational Change: Reflections on the Practice of Instructional and Transformational Leadership. Cambridge Journal of education 33(3): 329-352.

Hallinger, P. (2005). Instructional Leadership and the School Principal: A Passing Fancy That Refuses to Fade Away. Leadership and Policy in Schools 4(3): 221-239.

Hallinger, P. (2011). Leadership for Learning: Lessons from 40 Years of Empirical Research. Journal of Educational Administration 49(2): 125-142.

Hallinger, P. \& Murphy, J. F. (2013). Running on Empty? Finding the Time and Capacity to Lead Learning. NASSP Bulletin 97(1): 5-21.

Harris, A. (2003). Teacher Leadership as Distributed Leadership: Heresy, Fantasy or Possibility? School leadership \& management 23(3): 313-324.

Harris, A. (2008). Distributed Leadership: According to the Evidence. Journal of Educational Administration 46(2): 172-188.

Harris, A. \& Spillane, J. (2008). Distributed Leadership through the Looking Glass. Management in Education 22(1): 31.

Hord, S. E. (2004). Learning Together: Leading Together. Changing Schools through Plcs. New York: Teachers College Press.

Hord, S. M. (2008). Evolution of the Professional Learning Community. National Staff Developement Council 29(3): 10-13.

Hord, S. M. (2009). Professional Learning Communities. National Staff Developement Council 30(1): 40-43.

Horng, E. L., Klasik, D. \& Loeb, S. (2010). Principal's Time Use and School Effectiveness. American Journal of Education 116(4): 491-523.

Hulpia, H., Devos, G. \& Rosseel, Y. (2009a). The Relationship between the Perception of Distributed Leadership in Secondary Schools and Teachers' and Teacher Leaders'

International Journal of Educational Best Practices (IJEBP)

Vol. 3 No. 2 October 2019

ISSN: 2581-0847

DOI: 10.31258/ijebp.v3n2.p10-27 
Job Satisfaction and Organizational Commitment. School Effectiveness and School Improvement 20(3): 291-317.

Hulpia, H., Devos, G. \& Van Keer, H. (2009). The Influence of Distributed Leadership on Teachers' Organizational Commitment: A Multilevel Approach. The Journal of Educational Research 103(1): 40-52.

James Ang, J. E. \& Balasandran, R. (2009). Kepimpinan Instruksional. Satu Panduan Praktikal. Kuala Lumpur: PTS Professional.

Jazzar, M. \& Algozzine, B. (2007). Keys to Successful 21st Century: Educational Leadership. United States: Pearson Education, Inc.

Kowalski, T. J. (2010). The School Principal. Visionary Leadership and Competent Management. New york: Routledge Taylor and Francis Group.

Krejcie, R. V. \& Morgan, D. W. (1970). Determining Sample Size for Research Activities. Educ Psychol Meas.

Leithwood, K., Harris, A. \& Hopkins, D. (2008). Seven Strong Claims about Successful School Leadership. School Leadership and Management 28(1): 27-42.

Leithwood, K. \& Louise, K. S. (2012). Linking Leadership to Student Learning. San Francisco, USA. Jossey-Bass, A Wiley Imprint.

Marzano, R. J., Waters, T. \& Mcnulty, B. A. (2005). School Leadership That Works: From Research to Results. ERIC.

Mascall, B., Leithwood, K., Strauss, T. \& Sacks, R. (2009). The Relationship between Distributed Leadership and Teacher's Academic Optimism. Dlm. Harris, A. (pnyt.). Distributed Leadership: Different Perspectives hlm. 81-100. London: Springer.

Muijs, D. \& Harris, A. (2006). Teacher Led School Improvement: Teacher Leadership in the Uk. Teaching and teacher education 22(8): 961-972.

Spillane, J. \& Diamond, J. (2007). Taking a Distributed Perspective. Dlm. Spillane, J. \& Diamond, J. (pnyt.). Distributed Leadership in Practice, hlm. 1-15. New York: Teachers College.

Spillane, J. P., Halverson, R. \& Diamond, J. B. (2001). Investigating School Leadership Practice: A Distributed Perspective. Educational researcher 30(3): 23-28.

Spillane, J. P., Halverson, R. \& Diamond, J. B. (2004). Towards a Theory of Leadership Practice: A Distributed Perspective. Journal of Curriculum Studies 36(1): 3-34.

International Journal of Educational Best Practices (IJEBP)

Vol. 3 No. 2 October 2019

ISSN: 2581-0847

DOI: 10.31258/ijebp.v3n2.p10-27 
Timperley, H. S. (2005). Distributed Leadership: Developing Theory from Practice. Journal of curriculum studies 37(4): 395-420.

Uhl-Bien, M. (2006). Relational Leadership Theory: Exploring the Social Processes of Leadership and Organizing. The Leadership Quarterly 17(6): 654-676.

Wahlstrom, K., Louis, K., Leithwood, K. \& Anderson, S. (2010). Investigating the Links to Improved Student Learning: Executive Summary of Research Findings. Retrieved from The Wallace Foundation website: http://www. wallacefoundation. org

Wahlstrom, K. L. \& Louis, K. S. (2008). How Teachers Experience Principal Leadership: The Roles of Professional Community, Trust, Efficacy, and Shared Responsibility. Educational administration quarterly 44(4): 458-495.

Zainudin, A. (2012a). Research Methodology and Data Analysis. Shah Alam: UiTM Press. 